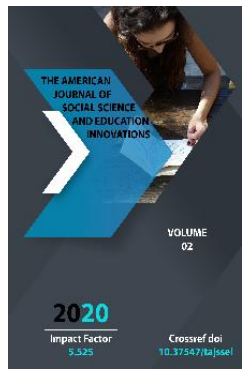

Journal Website: http://usajournalshub.c om/index,php/tajssei

Copyright: Original content from this work may be used under the terms of the creative commons attributes 4.0 licence.

\section{Importance Of Ancestoral Heritage}

\author{
Qudratulla Omonov \\ Professor, Doctor Of Philological Sciences, Tashkent State University Of Oriental Studies, \\ Uzbekistan
}

Nodir Karimov

Phd Student, Tashkent State University Of Oriental Studies, Uzbekistan

\title{
ABSTRACT
}

Central Asia is the land of great scholars. There has been a two time renaissance period - that is, a rise and prosperity in material and cultural life -in the region. The great scholars of this country have made invaluable contributions to world civilization. In particular, it is difficult to imagine the development of mathematics, medicine, astronomy, history, literature, philosophy and other religious and secular sciences without their share. It is the duty of every nation to study, propagate the heritage of its ancestors and strive to be a generation worthy of them. A range of work is being done in Uzbekistan to study the heritage of Central Asian scholars. This article summarizes the main work being done to study the heritage of Central Asian scholars. The tasks of today's youth are analyzed.

\section{KEYWORDS}

“New Uzbekistan”, Islamic Civilization, Central Asian scholars, renaissance, cultural heritage, Muslim Renaissance, Islam.

\section{INTRODUCTION}

\section{"New Uzbekistan" - the Third Renaissance} Due to the recent reforms, the phrase "New Uzbekistan" is often mentioned when talking about Uzbekistan. It is a recognition of the tremendous achievements we have made, that we have entered a completely new stage of development. Indeed, in "New
Uzbekistan", as in all areas, significant work is being done to study the heritage of Central Asian scholars, to convey it to Uzbek people and the world, to show recognition and respect. It is no coincidence that in recent years in order to further improve the study and teaching of ancestral heritage in 
Uzbekistan, the Center for Islamic Civilization, Islamic Academy, Mir Arab madrasah, Imam Bukhari, Imam Termezi, Imam Moturidi International Research Centers, Youth Academy and many other research centers, academies, special schools are being established. In these institutions, the scientific heritage of the ancestors is systematically studied and applied to life with the achievements of modern development. In the words of the President of the Republic of Uzbekistan Shavkat Mirziyoyev: "In today's world, where the glorious power of our people is in full swing, it is true to say that a new awakening is being laid in Uzbekistan the foundation of the Third Renaissance" [1].

Renaissance (French: Renaissance; Italian: Renasci) - lexical meanings such as rebirth. The famous German orientalist A. Metz was the first to use the term in a metaphorical sense, that is, in relation to the period, century and style in which culture flourished [2].

Until now, in the IX-XII and XIV-XVI centuries in the regions of Central Asia there was a rise in material and cultural life, prosperity, that is, the "Eastern Renaissance". The term "First Renaissance" is also used in relation to the IXXII centuries. The period after the Mongol invasion, ie the development of the XIV-XVI centuries, is associated with the period of Amir Temur and the Temurids [3].

The Resolution of the President of the Republic of Uzbekistan No. PP-3420 “On measures to establish the Center of Islamic Civilization" describes this period as follows: "The invaluable contribution of the great scholars and thinkers to the development of world science and culture, the sacred religion of Islam in the Middle Ages and beyond, the first Eastern Renaissance in the history of the world - the Muslim Renaissance - is rightly recognized by the world scientific community. In the early Middle Ages, the great scientific ideas and discoveries created by Central Asian scholars in the fields of history, geography, philosophy, culture and art, architecture, along with the exact sciences such as mathematics, astronomy, physics, chemistry, geodesy, pharmacology, medicine, became the world's science and civilization and made a sharp turn in the development.

Despite all the difficulties and hardships of their time, these scholars and thinkers were always faithful to their duty to the development of science, humanism and enlightenment, and showed true spiritual courage, and their great services to Uzbek people and humanity earned them respect and attention, especially during independence. .

The scientific heritage created by Central Asian great ancestors and amazed the whole enlightened world today is the spiritual property of not only one nation or people, but of all mankind, this priceless wealth is a source of wisdom and knowledge for new generations, and most importantly, a solid foundation for new discoveries. There is no doubt that it will serve for new discoveries" [4].

This means that today's youth must create a Third Renaissance period in Central Asia that is worthy of their ancestors. After all, the long history of Central Asian people, its unparalleled culture, the heritage of brave ancestors, invaluable ancestors always motivate today's generation to make new discoveries, new milestones.

THE MAIN RESULTS AND FINDINGS

A brief review of ancestral heritage 
Historical monuments and written sources that have survived to the present day testify to the flourishing of science and culture in Uzbekistan for a long time, especially in the middle Ages, today in the territory of Uzbekistan.

More than 7,000 cultural heritage masterpieces, thousands of archeological sites and excavations are proof of this. They play an invaluable role in the study of cultural life in ancient history, the way of life of Central Asian ancestors. Preserving and studying the heritage of Central Asian ancestors, passing it down from generation to generation is a priority for today's generation.

Cultural and natural heritage is the material and cultural wealth of the past. Examples of folklore, written literature, art, architecture, etc. passed down from ancestors to generations. The heritage of the ancestors will be consistent and firmly connected with the history of the people who created it; literary and spiritual memoirs, material and cultural monuments of this people, created and preserved from ancient times to the present day. The rich literary and cultural heritage of the Uzbek people began with the written history of the Achaemenids (558-330 BC), Seleucids (312-64 BC), Orkhon-Yenisei stone inscriptions, Turkic (Uyghur) manuscripts, the Turkish Khanate (552 -745), the Arab Caliphate (632-1258) and subsequent periods, in particular Amir Temur and the Temurids, Shaybanids, Ashtarkhanids, the Three Khanates, the Russian occupation, the Soviet regime and, finally, the oral, written and material memoirs and monuments built during the years of independence. These include the traditions, customs, holidays of the Uzbek people, examples of folk art, sources in the field of literature and science, works of fine and applied arts and music, ancient inscriptions and archeological finds, colorful architectural monuments. The preservation and study of literary and cultural heritage has both historical and educational value. These are the national pride of the Uzbek people [5]. Indeed, the great scientific heritage of Central Asian great scholars will play an important role in the development of today's children as a harmoniously developed generation for thousands of years to come.

\section{Uzbekistan is the land of great scholars}

The contribution of thinkers born and raised in the land of Central Asia to the development of world science was recognized and studied for centuries. As noted in the book "High spirituality is an invincible force", the international community recognizes and acknowledges that Uzbekistan's ancient and beautiful land is one of the cradles not only of the East, but also of world civilization. From this sacred land no great people, scientists, scholars, politicians and commanders emerged and became an integral part of universal civilization and culture. We are very proud of the invaluable services of the great scholars who were born and raised in Uzbekistan in the rise of secular and religious sciences, especially in the field of Islam. [6]

Uzbekistan is the land of great scholars. Muhammad ibn Ismail al-Bukhari, the sultan of hadith, who shook the world with his knowledge, Musa al-Khwarizmi, the founder of algebra, the author of "Fundamentals of Astronomy" and the basic information about the structure of the fundamental universe and the size of the earth, Ahmad Fergani was a great encyclopedic scholar, and Abu Rayhan Beruni was the first to create a globe [7], Abu Ali ibn Sino, known as the father of medicine, Abu Nasr al-Farabi, the great scientist known 
as the "Aristotle of the East", Mirzo Ulugbek, the great astronomer who described the position and location of 1018 stars in the 15th century, was awarded the title of "Muslim reformer" and Imam Moturudi, a leading scholar of theology, and Burhaniddin Marghinani, one of the Islamic jurists who wrote under the title "The Document of Religion and Nation", Hazrat Bahauddin Naqshband, a world-famous scholar, said, "Let your heart be in Allah and your hands be in labor", Alisher Navoi [8], the founder of the Uzbek language, who shone as a shining star in the history of world literature, recognized more than 500 poets and fuzalas in his "Majolis-ul-nafois" and "Nasoimul-muhabbat" works, and Imam Abu Isa at-Termizi [9], alHakim at-Termizi [10], Qaffol Shoshi, Khoja Ahror, Bahovuddin Naqshband, Ahmad Yassavi, Sufi Alloyar, Mahmud al-Zamahshari, Sahibkiran Amir Temur, Zahiriddin Babur, Jaloliddin Manguberdi and others our descendants of thousands of saints, scholars, and nobles were born, grew up and became famous in the world [11].

Universal ideas of the thinkers of the Great East: Khorezmi's secular discoveries and Beruni's scientific and socio-moral views, Farobi's advanced ideas about a just society, mature people, Ibn Sina's teachings in the field of spiritual divinity and medicine, Alisher Navoi's philosophical observation of the perfect man, the universal ideas put forward in the ghazals of Babur and Mashrab, the activities of the Jadid enlighteners of the beginning of the last century - such as Abdullah Qadiri, Abdulhamid Cholpon, Abdurauf Fitrat, Muhammadsharif Sofizoda also help to know the basics of Uzbek spirituality.

There is wisdom in the fact that the scholars who saw the sight of Allah will settle in Uzbek native land and lie in the soil of this land forever. It is the duty of each of us to study their heritage in depth, to learn from them, to be a generation worthy of Central Asian scholars.

\section{Central Asian ancestors are unparalleled in science and courage}

Islam plays an important role in the Eastern Renaissance. It is mentioned in the sources that Uzbek great scholars knew the Qur'an and the hadiths perfectly from their childhood. After all, Islam has always encouraged people to be zealous and courageous in acquiring knowledge and passing it on to others.

Regarding interest in knowledge, Allah says in the Qur'an:

"Say, "Are those who know equal to those who do not know?" Only they will remember [who are] people of understanding" (Surah az-Zumar: 9)

The Prophet (peace and blessings of Allaah be upon him) described the virtue of acquiring knowledge as follows: "Whoever follows the path of seeking knowledge, Allaah will guide him to the path of Paradise." (Reported by Muslim).

The Prophet (peace and blessings of Allaah be upon him) also said: "It is better for a person to learn a chapter of knowledge than the world and what is in it." (Narrated by Imam ibn Abdul Bar Hasan al-Basri).

Islam has made it obligatory for Muslims to follow the path of progress, and has encouraged people to seek knowledge, because nothing but knowledge can guide the human personality, nor can it lead to progress. 
Only those who have knowledge appreciate the blessings of Allah Almighty. Shows courage in possessing it and passing it on to others.

In Islam, qualities such as zeal and courage in people are valued and propagated. In particular, Central Asian great scholars, Imam al-Bukhari, the sultan of the hadith kingdom, is also characterized by this quality. His zeal and courage in compiling hadiths are especially commendable. Al-Mubarakfuri, one of the great scholars, said: "Imam al-Bukhari was tolerant of hardships, diligent in his work, and did not like to entrust his work to anyone".

Enthusiasm is used in the sense of effort, passion, enthusiasm, a strong, earnest commitment to action. An enthusiastic person is understood to be a courageous person who works with all his might.

The Prophet (peace and blessings of Allaah be upon him) said: "Allaah loves the zealous among His slaves" (Narrated by al-Bukhaari). That is, whoever does everything with zeal and courage, whether religious or secular, he will be blessed by Allah Almighty and he will achieve what he has set out to do. For effort is from the slave, and it is from Allah to bless and increase it.

Anushervon asked Justice Minister Buzurjmehr, "What is zeal, courage?" Buzurjmehr replied, "The power of the heart". Anushervon asked him again, "Why not the strength of the hand?" Buzurjmehr: "If there is no strength in the heart, there is no strength in the hand. The strength of the hand depends on the strength of the heart".

Indeed, when a person works with zeal and courage from the heart, he not only achieves his goal, but more than that. Muhammad
Jawhar Zamindor says: "Diligence works to achieve a goal. "If you don't have the motivation, you don't have the ability to be an example to others".

Many enthusiasts have always been an example to others. In particular, the great jurist Imam Abu Yusuf (r.a.) is an example of this. Abu Haneefa (may Allah be pleased with him) said about him: "Your intellect was low, and your perseverance, zeal and courage saved you from it" [12].

Central Asian scholars showed courage and bravery not only in science but also in the defense of the homeland. Suffice it to recall the events between Sheikh Najmiddin Kubro and Genghis Khan.

Such qualities as zeal and courage in the faces of Central Asian scholars are an example for generations. The heritage of Central Asian scholars is an inexhaustible treasure. The more we approach Him, the deeper we understand the world and man. New facets of the incomparable intellect, strength, and creative potential bestowed on man will be revealed. Such discoveries lead mankind to perfection, serve the longevity and perfection of future generations.

\section{A country that values its cultural and natural heritage}

In recent years, the study and promotion of ancestral heritage has been noted as a priority of public policy. In particular, the Center for Islamic Civilization in Uzbekistan, established in 2017, has the following tasks:

- Central Asian scholars compatriots who made a great contribution to the development of Islam - Imam Bukhari, Imam Termezi, Hakim Termezi, Abu Mansur Moturudi, Abu Muin Nasafi, 
Qaffol Shoshi, Abdulkhaliq Gijduvani, Najmiddin Kubro, Burhaniddin Marginoni, Bahauddin Naqshbandi, Khoja Ahror Valiy in-depth research, their scientific and spiritual courage, the widespread promotion of great human qualities;

- The role and importance of the legacy of such scientists and thinkers as Muhammad Khorezmi, Ahmad Fergani, Abu Nasr Farobi, Abu Rayhan Beruni, Abu Ali Ibn Sino, Mahmud Zamakhshari, Mirzo Ulugbek, Ali Kushchi in the development of historical and modern civilization, who left an indelible mark on the history of world science. The implementation of such issues as the deep revelation of the human nature of the works of classical literature and art, such as Alisher Navoi, Zahiriddin Muhammad Babur, Kamoliddin Behzod, Mahmud Muzahhib, was assessed at the level of state policy [13].

In 2017, the Imam Bukhari International Research Center was established.

It is necessary to study the great scientific and religious heritage of Central Asian compatriot Imam Bukhari and other thinkers who have made an invaluable contribution to the development of hadith science, to widely disseminate scientific and explanatory translations and comparative texts of their works among our people and the world community. - The primary task of the Center is to develop and implement measures.

\section{In 2017, the Imam Termezi International Research Center was established.}

The main goals and objectives of the center are to study in depth the unique heritage of the great scholar, Central Asian compatriot Abu Isa Termizi (Imam Termizi) and Termez scholars, who made a great contribution to the development of Islam. It is aimed at wide promotion among the public, preservation and development of our national and religious values, on this basis to educate the younger generation in the spirit of noble ideas, to strengthen in their hearts a sense of love and devotion to the Motherland.

\section{In 2020, the Imam Moturidi International Research Center was established.}

This resolution specifically assigned the task of translating the books of Imam Moturidi and the legacy of the teachings of Moturidi, Imam Moturidi, Imam Nasafi and other great thinkers into modern languages, in-depth study of their manuscripts.

In recent years, many more institutions have emerged to study and promote the heritage of our ancestors. Not only are they studying the written heritage of scholars, but they have established constant relationships with leading foreign scholars who are leaders in the field. For example, the Imam Bukhari International Research Center alone has signed memorandums of cooperation with more than 15 leading Islamic research centers and universities around the world. Hundreds of local and international conferences on the heritage of Central Asian scholars are held in Uzbekistan every year. In them, the results of the latest research are systematically discussed and disseminated to the general public.

\section{CONCLUSION}

At the heart of all reforms is the idea of creating a comprehensively developed Uzbekistan. The well-being of Central Asian scholars is the main goal of state policy. It is no exaggeration to say that the driving force behind the reforms being carried out under the leadership of Shavkat Mirziyoyev is 
today's youth. The established academies, centers, special schools should all serve as places for scientific growth and development of young people who are the creators of the future. These institutions must perform such functions as the Mamun Academy, which played an important role in the development of the Eastern Renaissance - the Muslim Renaissance, "Bayt ul-Hikma", ie "House of Wisdom", the scientific school of Mirzo Ulugbek, formed in Samarkand. They plan to raise a generation that will create a "New Uzbekistan" - the Third Renaissance. At the same time, it should be noted that all layers of the unique scientific heritage of Central Asian scholars have not yet been fully explored and are waiting for their researchers. This is evidenced by the more than 100,000 manuscripts kept in the book funds of our country, most of which are included in the UNESCO World Heritage List. As noted by President Shavkat Mirziyoyev, "Everyone glorifies their history. But nowhere is there such a rich history as in our country, great scholars like our ancestors. We must study this heritage deeply and be able to convey it to our people and the world".

\section{REFERENCES}

1. https://uza.uz/oz/politics/prezidentshavkat-mirziyeevning-zbekistonrespublikasi-musta-31-08-2020

2. Адам Мец. Мусульманский Ренессанс. Перевод с немецкого, предисловие, библиография и указатель Д.Е.Бертельса. - М.: Наука, 1966. - С. 456.

3. Хайруллаев М. Ўрта Осиёда илк Уйғониш даври маданияти. - Тошкент: Фан, 1994. - 136 бет.; Сулаймонова Ф. Шарқ ва Ғарб. - Тошкент: Ўзбекистон, 1997. - 314-346-бетлар;.Ширинов Т.
Тарихдан этюдлар. - Тошкент: Шарқ, 2014. - 336 бет.

4. https://lex.uz/docs/3600059

5. Ўзбекистон миллий энциклопедияси. 1жилд. А. - Тошкент: “Ўзбекистон миллий энциклопедия" Давлат илмий нашриёти, 2004 - 182-бет.

6. http://uza.uz/oz/society/buyuk-allomalarkamolga-etgan-zamin-18-07-2016

7. Каримов, Н. Р. (2018). КРАТКИЙ ОБЗОР РАБОТ БЕРУНИ И ЕГО РОЛИ В ЧЕЛОВЕЧЕСКОЙ ЦИВИЛИЗАЦИИ. In Лучшая студенческая статья 2018 (рр. 85-91).

8. http://muslim.uz/index.php/rus/maqolalar /item/10520-zbekiston-buyuk-allomalaryurti

9. Каримов, Н. Р. (2018). ВКЛАД МУХАММАДА МАНСУРА АЛИ В ИЗУЧЕНИЕ НАУЧНОГО НАСЛЕДИЯ АБУ ИСА ТЕРМИЗИ. In НАУКА И ИННОВАЦИИ В ХХІ ВЕКЕ: АКТУАЛЬНЫЕ ВОПРОСЫ, ОТКРЫТИЯ И ДОСТИЖЕНИЯ (pp. 198-200).

10. Дониёров, А. Х., \& Каримов, Н. Р. (2018). " КИТАБ АЛ-ХИКМА" И" ХИКМА" В НАУЧНОМ НАСЛЕДИИ ХАКИМА ТИРМИЗИ. In ЛУЧШАЯ НАУЧНАЯ СТАТЬЯ 2018 (рp. 48-52).

11. http://fargonaziyo.uz/ozbekiston-buyukallomalar-yurti/

12. http://muslim.uz/index.php/maqolalar/ite m/20199-allo-taologa-khush-jo-uvchifazilat-egasi

13. Ўзбекистон буюк алломалар юрти // Тузувчи ва нашрга тайёрловчи: Убайдулла Уватов. - Тошкент: Маьнавият, 2010. - 350 бет. 